\title{
RANCANG BANGUN MESIN PEMIPIL JAGUNG METODE POROS HELIX KAPASITAS 600KG/JAM DENGAN PENGGERAK MOTOR LISTRIK 2 HP
}

\author{
Achmad Sunarto, Mochamad Aziz, Prabowo Wahyu Wicaksono, Tri Waris Saputro, \\ Haryanto, Agus Slamet
}

\author{
Program Studi Teknik Mesin Jurusan Teknik Mesin Politeknik Negeri Semarang \\ Jl. Prof. Soedarto, SH, Tembalang, Semarang 50275 \\ Email:
}

\begin{abstract}
Abstrak
Jagung merupakan hasil pertanian yang menjadi pilihan mayoritas petani. Pada umumnya para petani jagung mengolah serta memipil jagung secara manual (tenaga manusia) tanpa menggunakan alat bantu mesin, sehingga memerlukan waktu yang lama. Mesin ini dirancang untuk mendesain ulang mesin pemipil jagung yang ada di Politeknik Negeri Semarang yang memiliki kapasitas produksi rendah. Tujuan penelitian ini adalah memenuhi proses pengolahan panen jagung dimana dapat menambah produktifitas, kualitas hasil pipilan jagung. Metodologi yang digunakan adalah dari data yang diperoleh dari studi literatur, pembuatan alat, perakitan dan uji kemampuan. Proses pemipilan jagung adalah dengan cara memasukan 4 buah jagung sekaligus ke dalam dua poros pemipil dengan diameter $50 \mathrm{~mm}$. Hasil yang dicapai dari pembuatan mesin ini yang dioperasikan selama 6 jam/hari adalah mampu memipil biji jagung dengan kapasitas produksi $600 \mathrm{~kg} / \mathrm{jam}$.
\end{abstract}

Kata Kunci : “rancang bangun”, “mesin pemipil jagung”, “kelompok tani”.

\section{Pendahuluan}

Tanaman jagung (Zea Mays L.) merupakan produk pertanian yang mengandung nilai gizi yang hampir sejajar dengan beras yang memiliki keluwesan lebih. Selain sebagai bahan makanan pokok, jagung bisa diolah menjadi beragam produk industri makanan. Diantaranya jagung dapat diolah menjadi sirup, minyak nabati, aneka makanan kecil, maizena, margarine, dan bir. Jagung juga dapat diproses menjadi bahan campuran makanan ternak, terutama unggas (Haryoto, 1995).

Sebelum dilakukan pemipilan jagung dijemur sampai kering (Kadar air bji 18\%-20\%). Pemipilan dapat menggunakan tangan atau alat pemipil jagung bila jumlah produksi cukup besar. Pada dasarnya "memipil" jagung hampir sama dengan proses perontokan gabah, yaitu memisahkan biji-biji dari tempat pelekatan. jagung melekat pada tongkolnya, maka antara biji dan tongkol perlu dipisahkan.(Kementrian Pertanian, 2015)

Luas panen dan produksi jagung di Provinsi Jawa Tengah pada tahun 2015 di 35 (tiga puluh lima) kota madya dan kabupaten yang terluas adalah Kabupaten Grobogan yang menduduki urutan pertama dengan luas panen sebesar 112.700 ha dengan produksi 700.941 ton sedangkan rata-rata produktivitas sebesar $62.20 \mathrm{ku} / \mathrm{Ha}$. Hal ini menunjukan bahwa rata-rata produktivitas tersebut masih rendah (BPS Provinsi Jawa Tengah, 2015).

Masalah yang dihadapi petani jagung di Kabupaten Grobogan adalah produktivitas yang masih rendah yaitu 6.22 ton/ha. Banyak faktor yang menyebabkan produktivitas rendah antara lain keterbatasan modal untuk membeli sarana produksi berupa benih, pupuk dan obat-obatan. Penyebab lain rendahnya produktivitas jagung karena tidak sebandingnya hasil produksi jagung dengan tenaga kerja untuk memproses hasil panen jagung (BPS Provinsi Jawa Tengah, 2015).

Untuk itu dibutuhkan mesin pemipil jagung yang dapat mengolah hasil panen jagung secara efisien. Mesin pemipil jagung merupakan sebuah mesin yang digunakan untuk memisahkan biji jagung dari dongkolnya. Pemisahan biji jagung dari dongkolnya biasanya dilakukan menggunakan tangan yang membutuhkan tenaga yang sangat melelahkan dan juga hasil yang kurang. 
Sebelumnya telah diciptakan "Rancang Bangun Mesin Pemipil Jagung Dengan Kapasitas 100 (Kg/Jam)" oleh Nur Fuad Adi Azka, Dkk. 2017. Mesin tersebut menggunakan motor bakar dan didukung disk pemipil berjumlah satu buah. Setelah dilakukan analisa permasalahan dari mesin tersebut maka mesin tersebut memiliki beberapa kekurangan yaitu jumlah disk hanya berjumlah satu buah sehingga kapasitas pemipilan tiap jam kurang optimal bila digunakan di Grobogan yang merupkan jumlah produksi terbesar di Jawa Tengah. Hasil pemipilan jagung menggunakan disk pemipil hasilnya kurang merata. Menurut Kepala Seksi Non Agro Energi dan SDM Disperindag, ada tiga dusun yang belum terjangkau listrik yaitu Dusun Sendang Desa Sambirejo Kecamatan Wirosari, Dusun Sumberejo Desa Mayahan Kecamatan Tawangharjo dan Dusun Ngijo Krasak Desa Mojoagung Kecamatan Karangrayu. Namun, ketiga dusun tersebut bukan merupakan dusun penghasil jagung terbesar di Grobogan karena penghasil terbesar ada di dusun yang berada di Kecamatan Geyer sehingga penggunaan motor bakar dinilai kurang efektif (Kompas.com Edisi Sabtu, 29 Juli 2017)

Dengan keterbatasan tersebut maka tercipta inovasi untuk mengembangkan mesin pemipil jagung dengan memperbanyak jumlah jagung dalam sekali proses sebanyak 4 buah jagung, menggunakan motor listrik sebagai penggerak utama dan listrik sebagai sumber energinya dan menggunakan crusher helix sebagai media untuk pemipilan jagung. Dan mesin ini juga dapat memproduksi biji jagung $600 \mathrm{~kg} /$ jam dengan presentase jagung yang terpipil sebesar 90\%. Anggaran pembuatan mesin ini menghabiskan dana sekitar Rp. 4.200.000,00.

Dengan adanya mesin ini diharapkan dapat memproduksi biji jagung yang memiliki kapasitas produksi yang lebih besar dan menghasilkan kualitas biji jagung yang layak. Dan dapat memudahkan dan mempercepat dalam pengolahan hasil panen jagung agar dapat memenuhi kebutuhan pasar.

\section{Metode Penilitian}

\subsection{Bahan Penilitian}

Bahan penelitian yang digunakan adalah berupa jenis jagung gigi kuda.

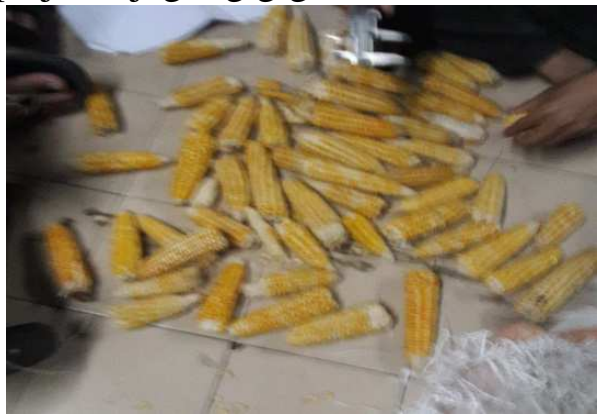

Gambar 1. Jagung Gigi Kuda

\subsection{Peralatan Penilitian}

Peralatan penelitian yang digunakan adalah peralatan alat ukur waktu dan alat ukur berat.

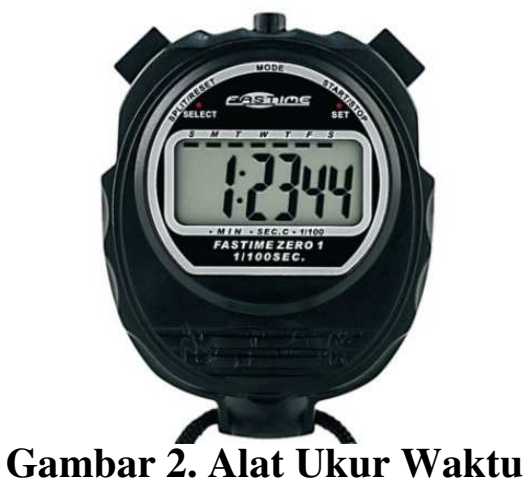

\subsection{Langkah Pengujian}

a. Siapkan 3 sampel jagung untuk pengujian. Setiap sampel terdiri dari 3 kali percobaan dengan diameter jagung yang sama dan panjang jagung berbeda, setiap percobaan terdiri dari 4 buah jagung dengan diameter dan panjang jagung yang sama.

b. Hidupkan mesin pemipil jagung.

c. Masukkan 4 buah jagung kedalam slot masing-masing secara bersamaan.

d. Mengukur waktu proses pemipilan jagung.

e. Menimbang berat jagung yang terpipil, tidak terpipil dan menghitung biji jagung dalam keadaan utuh (tidak hancur).

f. Mencatat hasil pengujian tiap sampel. 
g. Mematikan mesin pemipil jagung.

h. Ulangi langkah b,c,d,e,f,g sampai ketiga sampel selesai terpipil.

i. Mendokumentasikan hasil pengujian berupa biji jagung yang telah terpipil

j. Menentukan kesimpulan dari proses pengujian

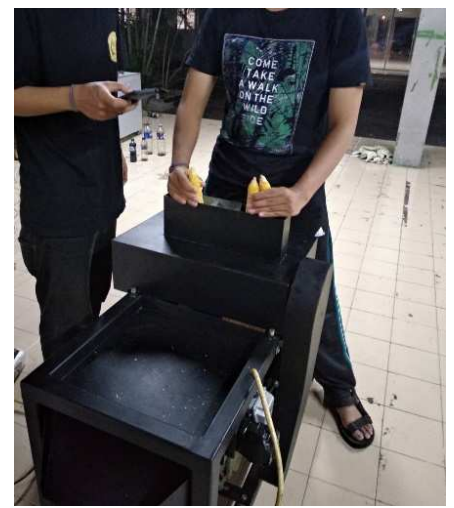

Gambar 3. Pengujian

\section{Hasil Pengujian dan Pembahasan}

\subsection{Hasil Pengujian}

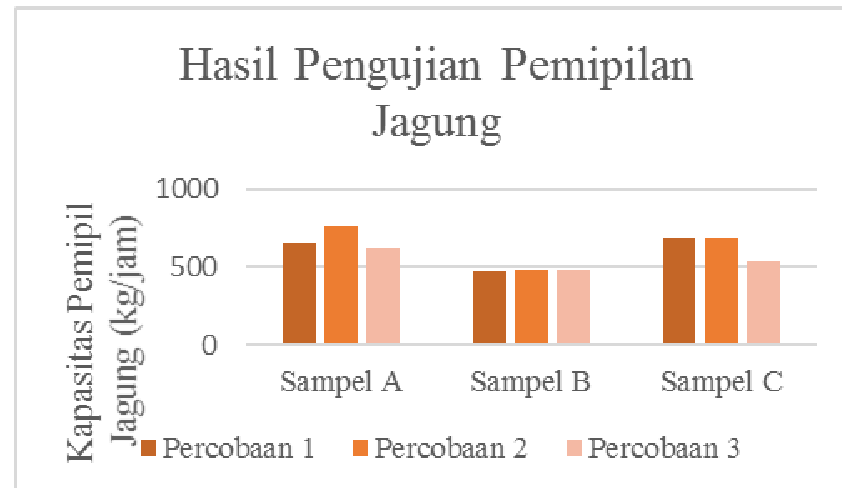

Gambar 4. Grafik Kapasitas Pipilan

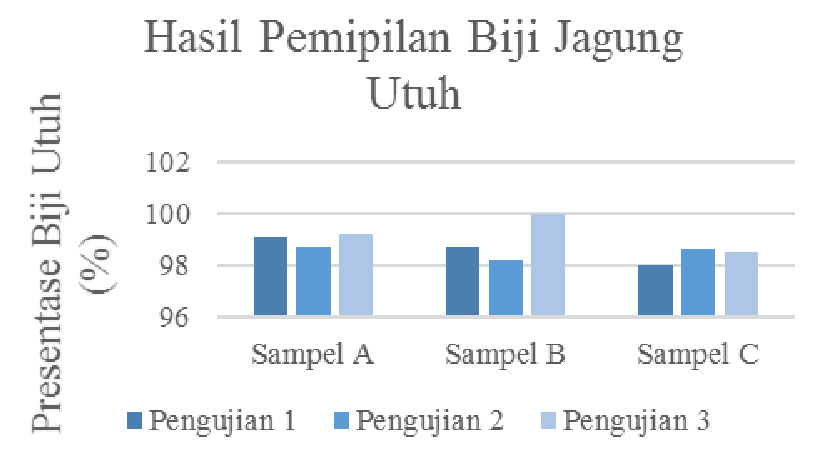

Gambar 5. Grafik Hasil Pemipilan

\subsection{Pembahasan}

1) Pada pengujian sampel A, dilakukan 3 kali pengujian jagung dengan diameter jagung sama 38 (mm) dan panjang jagung masing-masing pengujian 135 (mm), 130 $(\mathrm{mm}), 132(\mathrm{~mm})$. Hasil rata-rata pengujian pada sampel A didapatkan biji jagung yang terpipil 274 (gr), presentase biji jagung utuh sebesa $99,01 \%$ dan kapasitas biji jagung yang terpipil 677,02 (kg/jam).

2) Pada pengujian sampel $B$, dilakukan 3 kali pengujian jagung dengan diameter jagung sama $33(\mathrm{~mm})$ dan panjang jagung masing-masing pengujian $140(\mathrm{~mm}), 130$ $(\mathrm{mm}), 125(\mathrm{~mm})$. Hasil rata-rata pengujian pada sampel B didapatkan biji jagung yang terpipil 235 (gr), presentase biji jagung utuh sebesa 98,98\% dan kapasitas biji jagung yang terpipil 481,741 (kg/jam).

3) Pada pengujian sampel $\mathrm{C}$, dilakukan 3 kali pengujian jagung dengan diameter jagung sama $36(\mathrm{~mm})$ dan panjang jagung masing-masing pengujian 120 (mm), 122 (mm), $123(\mathrm{~mm})$. Hasil rata-rata pengujian pada sampel $\mathrm{C}$ didapatkan biji jagung yang terpipil 247 (gr), presentase biji jagung utuh sebesa 98,38\% dan kapasitas biji jagung yang terpipil 637,21 (kg/jam).

Dari hasil pengujian 3 sampel diatas dapat disimpulkan hasil pengujian pemipilan pada Rancang Bangun Mesin Pemipil Jagung Metode Poros Helix Kapasitas 600 kg/jam dengan Penggerak Motor Listrik 2 HP pemipilan yang paling baik didapat dari ratarata hasil pengujian sampel $A$ ukuran $D_{\text {jagung }}$ $38(\mathrm{~mm})$ panjang jagung $130-135(\mathrm{~mm})$ dengan hasil pemipilan $677,02(\mathrm{~kg})$, dalam waktu 1 (jam) dan pemipilan paling buruk terjadi pada rata-rata hasil pengujian sampel B dengan hasil pemipilan 481,741 (kg), waktu 1 (jam). Pada pengujian sampel B tidak memenuhi kapasitas yang direncanakan, hal ini karena diameter jagung terlalu kecil dan jarak ban pemipil terlalu lebar sehingga banyak jagung yang tidak terpipil. Untuk mengatasi masalah ini pada ban pemipil harus diganti dengan tebal ban 
yang lebih besar untuk jagung dengan diameter serupa. Presentase biji jagung yang utuh dari 3 sampel pengujian pemipilan semua melebihi $90 \%$. Kapasitas rata-rata dari 3 sampel percobaan 2 sampel telah mencapai kapasitas (600 kg/jam). Jadi, berdasarkan pengujian yang telah dilakukan tujuan Rancang Bangun Mesin Pemipil Jagung Metode Poros Helix Kapasitas 600 kg/jam dengan Penggerak Motor Listrik 2 HP telah tercapai.

\section{Kesimpulan.}

Berdasarkan tujuan Rancang Bangun Mesin Pemipil Jagung Metode Poros Helix Kapasitas 600 kg/jam dengan Penggerak Motor Listrik 2 HP dapat disimpulkan sebagai berikut:

1) Menghasilkan Rancang Bangun Mesin Pemipil Jagung Metode Poros Helix Kapasitas 600 kg/jam dengan Penggerak Motor Listrik 2 HP yang dapat berfungsi dengan baik.

2) Mampu memipil jagung sebanyak 4 buah secara bersamaan dalam satu kali proses.

3) Dari hasil pengujian pemipilan, Presentase biji jagung yang terpipil sebesar 94,36\% dan presentase biji jagung yang utuh sebesar 98,72\%.

4) Pengujian kinerja mesin pemipil jagung menghasilkan kapasitas maksimal pada jagung dengan diameter $38(\mathrm{~mm})$ dengan panjang $130 \quad(\mathrm{~mm})$ dengan waktu pemipilan 1,11 (detik) dengan kapasitas 759,4 (kg/jam).

\section{Daftar Pustaka}

- Aqil, Muhammad. 2010. Pengembangan Metodologi untuk Penekanan Susut Hasil pada Proses Pemipilan Jagung. Balai Penelitian Tanaman Serealia. Prosiding Pekan Serealia Nasional.

- Badan Standarisasi Nasional. 1998. Mutu Jagung Standar bahan Pakan.

- Budynas, Richard G dan J.Keith Nisbett. 2008. Shingley's Mechanical Engineering Design. New York:
McGraw-Hill Companies.Inc Jutz, Hermann dan Eduard Scharkus. 1985. Westermann Tables for The Metal Trade. New Dehli : Wiley Eastern Limited.

- Haryoto (1996). Teknologi Tepat Guna:

Membuat Alat Pemipil Jagung, Penerbit Kanisius.

- Hatorangan, Erick Febriana. 2007. Pengaruh Perlakuan Konsentrasi $\mathrm{NaCl}$, Kadar Air, dan Passsiing Terhadap Mutu Fisik Mi Basah Jagung Yang Diproduksi Dengan Menggunakan Ektruder Ulir Pemasak dan Pencetak. Central Library of Bogor Agricultural University

- Ir. H. Rahmat Rukmana. 1997. Usaha Tani Jagung. Penerbit Kanisius

- Khurmi, R.S dan J.K Gupta. 2005. A Textbook Of : Machine Design (S.I Units) New Delhi. Eurasia Publishing House.

- Nur Fuad Adi Azka, Dkk. 2017. Rancang Bangun Mesin Pemipil Jagung Dengan Kapasitas 100 (Kg/Jam). Semarang: Politeknik Negeri Semarang.

- Molt, Robert L. 2009. Elemen - Elemen Mesin dalam Perancangan Mekanis. Terjemahan Rines dkk. Yogyakarta : ANDI.

- Suhardi, B. (2008). Perancangan Sistem Kerja dan Ergonomi Industri, Direktorat Pembinaan Sekolah Menengah Kejuruan, Direktorat Jenderal Manajemen Pendidikan dasar dan Menengah, Departemen Pendidikan Nasional, Jakarta.

- Tarwaka, dkk (2004). Ergonomi untuk Keselamatan, Kesehatan Kerja dan Produktivitas, Uniba Press, Surakarta. 